\title{
Review Article \\ IMPROVING PRODUCTIVITY OF PULSES USING PLANT GROWTH REGULATORS: A REVIEW
}

\author{
DEOL J.S. ${ }^{1}$, SHYAM CHANDRIMA2 ${ }^{2}$, SHARMA RAJNI ${ }^{3}$, RAMANJIT KAUR ${ }^{* 4}$ AND MEENA S.L. ${ }^{5}$ \\ ${ }^{1}$ Professor, Punjab Agricultural University, Ludhiana, Punjab, 141004, India \\ ${ }^{2}$ Graduate Research Assistant, Department of Agronomy, Kansas State University, 3719 Throckmorton Plant Sciences Centre, Manhanttan, Kansas, 66506, USA \\ ${ }^{3}$ Asstt Agronomist, Punjab Agricultural University, Ludhiana, Punjab, 141004, India \\ 4Principal Scientist, ICAR-Indian Agricultural Research Institute, Pusa, New Delhi, Delhi 110012, India \\ ${ }_{5}^{5}$ rincipal Scientist, ICAR-Indian Agricultural Research Institute, Pusa, New Delhi, Delhi 110012, India \\ *Corresponding Author: Email - ramaan180103@yahoo.com
}

Received: May 25, 2018; Revised: June 15, 2018; Accepted: June 16, 2018; Published: June 30, 2018

\begin{abstract}
India ranks first both as producer and consumer of pulses. It is also the largest importer of pulses as the total domestic requirement outweighs total production. So, to attain self-sufficiency in terms of pulse production the constraints in cultivation need to be addressed. Pulse production faces a series of constraints which include its inherent physiological limitations. These limitations include lower germination percentage, source limitation, low leaf area development, indeterminate growth habit, $\mathrm{C}_{3}$ photosynthetic apparatus, slow initial dry matter accumulation, limited photosynthesis, hormones inhibitors, decline in nodule activity and diversion of metabolic energy to sinks for protein synthesis. To overcome these limitations simple agronomic techniques such as application of growth hormones are adopted. This paper critically reviews the physiological constraints of pulses and effect of growth regulators to improve these limitations and concomitantly increasing yield.

Keywords- Pulse, Physiological constraints, Growth regulators, Productivity
\end{abstract}

Citation: Deol J.S., et al., (2018) Improving Productivity of Pulses Using Plant Growth Regulators: A Review. International Journal of Microbiology Research, ISSN: $0975-5276$ \& EISSN: 0975-9174, Volume 10, Issue 6, pp.-1259-1263.

Copyright: Copyright@2018 Deol J.S., et al., This is an open-access article distributed under the terms of the Creative Commons Attribution License, which permits unrestricted use, distribution and reproduction in any medium, provided the original author and source are credited.

\section{Introduction}

India is the largest producer, consumer and exporter of pulses in the world. Being a cheap source of protein, high fibre content, vitamins and minerals along with unique ability to restore soil health, pulses have assumed the role of panacea for sustainable production. Keeping in view large benefits of pulses in agriculture and human health, the United Nations had proclaimed 2016 as the 'International year of Pulses'. Thus, considering the importance of pulses with respect to nutritional food security and environmental sustainability, there is utter need to improve pulse production [1]. Pulses are important component to sustain agriculture production as they possess wide adaptability to fit into various cropping systems and being leguminous in nature have been known for their soil ameliorative effects. Introduction of pulses in existing intensive cereal based cropping systems such as rice-wheat, the heavy nitrogen needs of the system can at least be partly met and the physical, chemical characteristics of the soil generally gets improved. Although 28.1 million hectares of land in India is under pulse cultivation with annual production of 18.31 million tonnes representing $34.88 \%$ of world area and 25.08 $\%$ of worlds pulse production [2]. Yet, stagnant pulse production over the last two decades has resulted in reduced per capita pulse consumption from 60 gm/capita/day in 1950-51 to $32 \mathrm{gm} /$ capita/day present [3]. Such reduced consumption is much lower than the actual recommendation of World Health Organization (WHO) of $80 \mathrm{~kg} /$ capita/day. This has also led in an increment in annual import of pulses overall from 0.50 million tonnes to 1.80 million tonnes during the last 5 years, causing a reduction in the contribution of pulses in the national food basket from $17 \%$ to $7 \%$ [3]. Thus, to increase production and productivity of pulses in India, there is dire need to identify the existing constraints in its production so that appropriate measures can be taken and more emphasis should be laid on new improved pulse production technologies, which intern will lead to increased production and productivity of pulse crops.
Even with best efforts, pulse cultivation in India faces a series of problems viz. biotic and abiotic stresses, pest management, socio-economic constraints etc. Besides this, pulse crops have inherent limitations such as poor germination, source limitation, slow dry matter accumulation, indeterminate growth habit, $\mathrm{C}_{3}$ photosynthetic apparatus, decrease in nodule activity, abscission of flowers and pods, higher energy requirement and reduced sink activity which intern will lead to lower yield and productivity. These limitations are generally physiological in nature and can be overcome with application of magic chemicals called plant growth regulators (PGRs).

Plant growth regulators - Plant growth regulators are chemical substances that at low concentration influence the growth and differentiation of plant cell, tissues and organs [4]. In other words, these act as chemical messengers for inter-cellular communication. These can be either biochemicals which are produced in plants (endogenous) or synthetic chemicals which are applied to plants exogenously [5]. These are applied to curtail excessive vegetative growth, to improve photosynthetic efficiency, improve source-sink relationship and better fruit retention $[6,7]$. Plant growth regulators are of following types [8]:

Classical plant hormones and growth regulatory substances: These include auxins, gibberellins, cytokinins, abscissic acid and ethylenes.

Growth substances that have phyto-hormonal activities: These include recently discovered growth substances such as polyamines, oligosaccharins, salicylates, jasmonates, sterols, turgorins, brassinosteroids, dehydrodiconiferyl alcohol glucosides, systemins and unrelated natural stimulators and inhibitors.

Physiological limitations and effect of plant growth regulators:

Lower germination percentage

Pulses suffer from low germination percentage due to external factors such as soil salinity, sensitivity to moisture regime etc. 
Application of growth regulators can help in overcoming these stresses and thus ensure higher germination percentage [9]. Srivastava, et al., (2011) [9] conducted an experiment to study the effect of brassinolide @. 0.1, 0.2, 0.3, 0.4, 0.5, 0.6, 0.7, $0.8 \mathrm{ppm}$ and control on germination of green gram (Vigna radiata L.). They reported that brassinolide application $(0.4 \mathrm{ppm})$ significantly improved green gram germination with highest germination percentage $(100 \%)$, germination index (1.89), speed of germination (1.53), coefficient of velocity of germination (59.3) and relative seed germination (126.4\%). It also resulted in higher seedling growth $(1.43 \mathrm{~cm})$ and relative root elongation $(134.5 \%)$. In general, brassinolides are known to enhance seed germination and cause elongation of hypocotyls, epicotyls and peduncles in dicots. Similar result with brassinolide application were obtained by [10] Chang and Cai (1988); Dong, et al., (1989); Hayat, et al., (2003) $[10,11,12]$. Akbari, et al., (2008) [13] reported that application of gibberelic acid $\left(G_{3}\right)$ significantly improved green gram germination and yield attributes in saline conditions. Chauhan, et al., (2009) [14] concluded apart from increasing germination percentage, $\mathrm{GA}_{3}$ application also results in higher radicle and plumule length. Previous researches have shown that, $\mathrm{GA}_{3}$ plays an important role in supplying stored assimilates in the germinating seeds to the growing embryo, thus significantly improves germination percentage and ensures proper plumule and radical development. Yadav and Singh, (2014) [15] reported enhanced germination percentage, radicle length and plumule length in SML-668 and K-851 varieties of green gram with 2,4-D application.

\section{Source limitation and lower leaf area development}

Another inherent cause leading to low yield in pulses is inadequate supply of nutrients to developing embryos [16]. The source is highly limited in pulses with lowering translocation of assimilates to the growing reproductive sinks. Yoshida, (1972) [17] stated that source size is important for productivity. Furthermore, in pulses overlapping of vegetative and reproductive phase, high energy requirement for protein formation, and unit allocation for dinitrogen reduction causes constant changes in source size and activity [18]. Inadequate source size in legumes is the consequence of factors like slow initial leaf area development (LAD) and dry matter accumulation. In pulses $L A D$ is slow at the beginning and increase afterwards. In cases of pulses like cowpea (Vigna unguiculata L.), green gram and black gram (Vigna mungo L.) LAD is very slow for first three to four weeks but later increase efficiently [19]. Yan and Wallace, (1995) [20] considered shoot biomass accumulation a major physiological-genetic component for crop yield accumulation. Islam, et al., (2010) [21] studied the effect of GABA [GA $3+$ abscisic acid (ABA)] on morphological characters of black gram and concluded that GABA (1.0 ppm) application resulted in significantly greater number of leaves per plant and leaf area index (LAl) at all crop growth stages., which ultimately lead to higher number of pods per plant and seed yield. Similar result was obtained in soybean (Glycine max L.) with 2,3,5-tri-iodobenzoic acid (TIBA) application [22]. TIBA is known to stimulate photosynthesis due to higher assimilative area production which leads to ensures better growth, development and higher yield. Parmar, et al., (2012) [23] reported that $\mathrm{GA}_{3}$ (20 ppm) applied at 20 and 40 days after sowing (DAS) significantly increased number of leaves per plant in summer green gram. Application of indole-3-acetic acid (IAA) was found to increase leaf numbers as well as yield-attributes such as number of pods per plant, seeds per pod and seed weight per plant due to better source development in green gram by Quaderi, et al., (2006) [24].

\section{Slow dry matter accumulation}

Pulses are characterized with slow initial dry matter accumulation due to their lower LAl, extinction coefficient and photosynthetic rates. Sheldrake and Saxena, (1979) [25] studied dry matter accumulation pattern in chickpea (Cicer arietinum L.) and concluded that around $60-80 \%$ of total dry matter is accumulated in onethird to one-fourth period in the life cycle which is mostly in post-flowering phase. Singh (2001) [26] conducted an experiment on green gram to study the effect of mepiquat chloride $(\mathrm{MC})$ at various concentrations and time of application and reported that $M C$ effectively reduced plant height and increased dry matter accumulation over control. MC was found to increase pods per plant, grains per pod and protein content in grains of green gram significantly over control. Grain yield and harvest index showed a significant increase over control with application of MC. Ganiger, et al., (2002) [27] concluded that application of TIBA and $\mathrm{GA}_{3}$ results higher total dry matter accumulation in cowpea. Similar result was obtained by Bai, et al., (1987) [28] with application of $\mathrm{GA}_{3}$ and 1-napthaleneacetic acid (NAA) in green gram. $\mathrm{GA}_{3}$ and NAA significantly improve translocation of assimilates thus resulting in dry matter accumulation and concurrently higher yields. Sengupta, et al., (2011) [29] studied the effect of brassinolide on green gram and found that brassinolide significantly improved dry matter accumulation both at 45 and 60 DAS. Ramesh and Ramprasad, (2013) [30] reported that application of plant growth regulators such as chlormequat chloride (CC), NAA, brassinosteroids and $M C$ result in higher crop growth rate (CGR) and net assimilation rate (NAR). Rahman, et al., (2004) [31] conducted a research trial to study the influence of $\mathrm{GA}_{3}$ and maleic hydrazide $(\mathrm{MH})$ on dry matter accumulation of soybean. They found $\mathrm{GA}_{3}$ to be more effective than $\mathrm{MH}$, and $\mathrm{GA}_{3}$ at $100 \mathrm{ppm}$ resulted in significantly higher root, stem, leaf dry matter and also higher CGR, NAR and relative growth rate (RGR).

\section{Indeterminate growth habit}

Inherently pulse crops possess indeterminate growth habit. Especially when summer rainfall is erratic, indeterminate plants acclimatize by continuing both vegetative growth and flowering over an extended period [32]. This results in unsynchronized maturity with prolonged duration and reduced yields. Due to indeterminate nature of pulses there is a continuous inter-organ competition for available assimilates between vegetative and reproductive sinks throughout the growth period resulting in inefficient allocation of photosynthates. This competition causes failure of pods to set seeds, low partitioning coefficient, poor harvest index, low seed yields and low overall seed quality. Withers and Forde, (1979) [33] found that stem of Lupinus albus to be active sites of $\mathrm{C}_{14}$ accumulation apart from its seed at all plant growth stages. Farrington and Pate, (1981) [34] showed in Lupinus angustifolia that removal of lateral branches below inflorescence resulted in greater pod number. Scully and Wallace, (1990) [35] considered effective dry matter partitioning to be important for higher yield in common bean (Phaseolus vulgaris L.). Thomson, et al., (2015) [36] reported $\mathrm{GA}_{3}$ application in pea (Pisum sativum L.) @ 100 ppm resulted in lowest number of days taken to first flowering. They attributed this due to early completion of vegetative growth and improved nourishment of plants following growth regulator application. However, delayed maturity has been also observed with growth regulator application. Upadhyay, (2002) [37] observed higher number of days taken to maturity with kinetin application in chickpea which also corresponded to higher no. of grains/pod, pods/plant, stover yield and seed yield.

\section{$\mathrm{C}_{3}$ photosynthetic apparatus}

Pulses being $\mathrm{C}_{3}$ plants are potentially low yielders and sometimes considered physiologically inefficient compared to $\mathrm{C}_{4}$ cereals such as sorghum (Sorghum bicolor L.), maize (Zea mays L.) etc. [38]. In $\mathrm{C}_{3}$ plants rubisco catalyses carboxylation and oxygenation to initiate photosynthesis but slow catalytic rate, low affinity for atmospheric $\mathrm{CO}_{2}$ and use of $\mathrm{O}_{2}$ as an alternative substrate for the competing process of photorespiration make rubisco inefficient [39]. Lower light saturation point and higher $\mathrm{CO}_{2}$ compensation point of $\mathrm{C}_{3}$ pulses generally reduce photosynthetic rate leading reduced yield. Furthermore, in the post-flowering period, a serious decline in photosynthetic rate has been observed which is attributed to factors such as loss of activity of ribulose 1,5-bisphosphate (RuBP) carboxylase and reduced total nitrogen content in leaves following the flowering period. A study was conducted by Fariduddin, et al., (2006) [40] in Aligarh to study the effect of 20-homobrassinolide on green gram. They reported that homobrassinolide applied at 10-8 M concentration increased photosynthetic rate by $33 \%$ with respect to control and seed weight at harvest by $27 \%$. Fariduddin, et al., (2008) [41] conducted another experiment to study the effect of 28homobrassinolide on green gram and reported significantly increased activities of carbonic anhydrase and nitrate reductase, leaf chlorophyll content, net photosynthetic rate, stomatal conductance and carboxylation efficiency irrespective of mode of application (seed treatment and foliar spray). Similar improvement was also observed in number of pods and seed yield at harvest. 
However, the results revealed that based on mode of application, seed soaking + foliage application > foliage application only > seed soaking > control. Dhashnamurthi, et al., (2013) [42] reported that exogenous ABA application (10-5 M) on green gram under prolonged drought situations resulted in improved wateruse efficiency with stable photosynthetic rates. This property of $A B A$ attributed to its ability to modify photosynthetic gas exchange properties along with opening of stomatal aperture. Application of NAA (20 ppm) was found to significantly increase relative chlorophyll content and photosynthetic rate in green gram [43]. Similar effect of growth regulators on chlorophyll content was found by Reddy, et al., (2009) [44].

\section{Decline in nodule activity}

In pulses such as cowpea, green gram and chickpea, the number and weight of nodules per plant increased up to flowering, but in post-flowering stage there is a sudden decline in number of nodules due to disintegration [19]. Sinha, (1977) [45] related the nodule activity in legumes to their growth and yielding capacity. Sinha, et al., (1988) [19] reported that there is decrease in nitrogen (amino nitrogen) per plant in legumes during post-flowering stage. In legumes, this level of nitrogen content especially in leaves shows their ability to utilize inorganic nitrogen which ultimately affect yield [19]. Similar study by Dangwal, et al., (2006) [46] in horse gram (Macrotyloma uniflorum L.) showed that the number of nodules and nitrogenase activity reached its peak in flowering period followed by decline afterwards, while there was no as such reduction in individual nodule fresh weight. Ali and Bano, (2008) [47] conducted an experiment to study the effect of ABA and kinetin on nodule senescence in chickpea and observed that kinetin delayed nodule abscission while ABA enhanced it. They further found that kinetin (10-5 M) application resulted in highest mean diameter $(1.76 \mathrm{~mm} / \mathrm{plant} / \mathrm{h})$ and nitrogenase activity $\left(8.5 \mathrm{nmol} \mathrm{C}_{2} \mathrm{H}_{4} / \mathrm{plant} / \mathrm{h}\right)$ of nodules, and finally produced significantly higher grain weight $(5.2 \mathrm{~g})$, seed index $(88.9 \mathrm{~g})$ and numbers of pods per plant (5.3). Such positive impact of kinetin was attributed to significantly decreased endogenous $A B A$ levels and increased leaf sugar content in late pod-filling stages which are the main donors of photosynthates to nodules. This resulted in delayed senescence and concomitantly led to higher yield. Medhi, et al., (2014) [48] studied the effect of growth regulators on nodulation in green gram and reported that NAA (50 ppm) application led to significantly higher number of nodules per plant, nodule fresh weight and dry weight. The underlying reason was attributed to enhanced translocation of photosynthates to nodules which improved nodule activity and stimulated yield attributes too.

\section{Pod and flower abscission}

In pulses each flower is capable of producing greater number of seeds, which makes its yield potential higher than cereals. But, high flower shedding due to limited photosynthesis, hormones, inhibitors, limited nitrogen availability, reduced light intensity in canopies, gas exchange in canopies, humidity, soil and water factors and other genetic factors reduces yield drastically [45]. In pulses, at later stages of crop growth a greater proportion of available photosynthates are stored in mature pods leading to shedding of immature pods [49]. Stevenick, (1957) [50] attributed this to the production of ABA particularly in pods of same inflorescence. Stress caused due to high temperature, low temperature, water or other may lead to production of $A B A$ in pulses. Limited nitrogen availability due to disintegration of nodules at the peak flowering stage further accelerate the shedding process. In pulses like green gram, flower and pod shedding is very common problem. In pigeon pea almost $80 \%$ flower produced are shed leading to very poor yield. [51] reported $37.9 \%, 46.0 \%$ and $53.7 \%$ flower drop in black gram, green gram and cowpea, respectively. This problem of flower shedding can be dealt either by breeding genetic lines which retain a large proportion of flowers produced or by spraying growth regulators at proper plant stages [38]. Foliar application of growth regulator is one of the latest trends followed in agriculture to tackle this constraint. Plant growth regulators when applied at the time of flowering not only increase the number of flowers on the plant significantly but also reduce the flower and pod drop [52]. Arora, et al., (2005) [53] studied effect of $M C$ and $\mathrm{GA}_{3}$ on soybean. $\mathrm{MC}$ (100 ppm) gave more number of flowers per plant (228) and simultaneously pods per plant (105) resulting highest pod setting percentage (45.94 \%). Yield attributes such as number of seeds per pod, seed index, seed yield per plot were also higher with MC (100 ppm). Similar effect on hastened flowering and decreased abscission was observed in green gram with application of cycocel (CCC) by Garai and Datta, (2002) [54]. Rao, et al., (2005) [55] determined the effect of MC, potassium nitrate, borax and triacontanol, applied alone or in combination, on flower abortion, pod setting and yield of chickpea. They observed that the application of $50 \mathrm{ppm} \mathrm{MC,} 1.25 \mathrm{ppm}$ Triacontanol (TRIA), $0.2 \%$ borax and $1 \%$ potassium nitrate resulted in the higher flower setting, 100-seed weight, biomass at harvest, seed yield, harvest index and lowest number of aborted flowers. Singh (2002) [56] reported that MC treated chickpea plants had more number of flower retention as compared to water spray treated plots. Bangal, et al., (1982) [57] stated the use of CCC for checking abscission of flowering and also, modifying crop canopy structure. Similar results with PGRs have been found by Thavaprakash, et al., (2006); Kandil, et al., (2011); Khalil, et al., (2006); Islam, et al., (2010) [58,59, 60, 61]. Ibrahim, et al., (2007) [62] reported in faba bean (Vicia faba L.) that application of benzyl adenine (BA), IAA or ancymidol reduced flower abscission percentage significantly. They observed, lowest flower abscission percentage 62.61 and $56.82 \%$ with application of BA during the two seasons respectively. In this study, application of $B A$ resulted in highest pod set followed by ancymidol and pod abscission percentage was lower in all growth regulation treatments compared to control. In another study, conducted by Shyam, et al., (2018) [63], they reported that foliar application of ethrel @ 1.0 I/ha at 55-60 DAS, significantly improved pod setting percentage by $15.4 \%$ in summer green gram.

\section{Higher energy requirement and reduced sink activity}

Nitrogen assimilation via $\mathrm{N}_{2}$ fixation involves higher metabolic energy expenditure than root uptake of nutrients due to high nitrogen requirement of nitrogenase enzyme and for growth and maintenance of root nodules [64]. This additional energy requirement results in diversion of energy to fix N2 rather than used for growth processes [65]. Sinclair and deWit, (1975) [66] stated that the higher protein content in grain legumes result in greater amount of photosynthates being used for synthesizing the protein. Munier-Jolain and Salon, (2005) [67] attributed lower productivity in legumes to the higher energy costs due to protein-rich seed production. Also, there is competition for photosynthates between early formed and late formed inflorescence, which results in low rate of photosynthetic influx to late formed ones. Thus, these are poorly formed and fail to form powerful sinks [18]. Binnie and Clifford, (1998) [68] examined sink characteristics of dwarf bean (Phaseolus vulgaris L.) and concluded that reproductive organs proximal to raceme received greater amount of photosynthates than those distal to raceme. Pate and Farrington, (1981) [69] conducted an experiment on Lupinus angustifolius and found that flowers attract assimilates more at bud stage than at later stages.

They observed that upper flowers gradually failed to impart assimilates and abscise while the lower ones regain sink strength once the upper flowers are shed. Studies have shown that, PGR application improve the sink development through higher number of pods per plant, seeds per pod, seed weight, harvest index and other important yield attributes. Ullah, et al., (2007) [70] reported significantly increased yield in cowpea with application of $1250 \mathrm{ppm}$ potassium naphthenate (Knap) which attributed to better sink development i.e., higher number of pods per plant, seeds per pod, 1000 seed weight and harvest index. Similar findings were found by Udensi, et al., (2013) [71]. They reported higher seed yield in different pigeon pea (Cajanus cajan L.) landraces followed by paclobutazole (PCB)+NAA application. In another experiment conducted in Gujarat, 2,4-dichlorophenoxyacetic acid (2,4-D) application @ 5 ppm resulted in significantly higher seed yield in pea [36].

\section{Conclusion}

Application of PGRs have been done long time especially in pulses. Our review suggests that, it has the potential of dealing with physiological limitations of pulses and enhancing their productivity. However, more research is needed to understand the effects of these PGRs from plant physiological point of view. There is also a need of creating awareness at grower level about the usefulness of these PGRs as well as ensuring their availability at widespread scale. 
Application of research: This review paper reviews and summarizes available information on the physiological effect of different plant growth regulators on enhancing pulse productivity.

Research Category: Plant growth regulators, Pulses

\author{
Abbreviations \\ 2,4-D= 2,4-Dichlorophenoxyacetic acid \\ $\mathrm{ABA}=$ Abscisic acid \\ $B A=$ Benzyl adenine \\ $\mathrm{CC}=$ Chlormequat chloride \\ CCC $=$ Cycocel \\ $C G R=$ Crop growth rate \\ DAS= Days after sowing \\ $\mathrm{GA}_{3}=$ Gibberellic acid \\ $\mathrm{GABA}=\mathrm{GA}_{3}+\mathrm{ABA}$ \\ IAA= Indole-3-acetic acid \\ Knap $=$ Potassium naphthanate \\ $L A D=$ Leaf area development \\ $L A l=$ Leaf area index \\ $M C=$ Mepiquat chloride \\ $\mathrm{MH}=$ Maleic hydrazide \\ $N A A=1-$ Napthaleneacetic acid \\ NAR $=$ Net assimilation rate \\ $\mathrm{PCB}=$ Paclobutazole \\ PGRs= Plant growth regulators \\ Ppm= Parts per million \\ $R G R=$ Relative growth rate \\ RuBP= Ribulose 1,5-bisphosphate \\ TIBA= 2,3,5-Tri-iodobenzoic acid \\ WHO $=$ World Health Organization
}

Acknowledgement / Funding: Author thankful to Punjab Agricultural University, Ludhiana-141004

\section{*Research Guide or Chairperson of research: Dr J S Deol}

University: Punjab Agricultural University, Ludhiana, 141004

Research project name or number: Nil

\section{Author Contributions: All author equally contributed}

Author statement: All authors read, reviewed, agree and approved the final manuscript

\section{Conflict of Interest: None declared}

Ethical approval: This article does not contain any studies with human participants or animals performed by any of the authors.

\section{References}

[1] Dubey V, Alam MS and Singh D (2017) International Journal of Agricultural Sciences 13(1), 132-137.

[2] FAO (2013) Data retrieved from http,//www.fao.org/faostat.

[3] Anonymous (2018) Data retrieved from htp,// http,//dpd.gov.in/strategy/preamble.htm

[4] Opkins WG and Huner NPA (2008) John Willey and Sons Inc. United States of America.

[5] Reddy TY and Reddi GHS (2011) Kalyani publishers, New Delhi, India.

[6] Kaur R, Rajni, Deol JS and Dass A (2013) Annals of Agricultural Research 34(4), 287-297.

[7] Kaur R, Singh K, Deol JS, Dass A and Choudhary AK (2015) Proc. Natl. Acad. Sci., India, Sect. B Biol. Sci. DOI 10.1007/s40011-015-0551-8.

[8] Gaspar T, Kevers C, Penel C, Greppin H, Reid DM and Thorpe TA (1996)
In Vitro Cellular and Developmental Biology-Plant 32, 272-289.

[9] Srivastava K, Raghava N, Shagun and Rahava RP (2011) Indian Journal of Science Research 2(3), 89-92.

[10] Chang JQ and Cai DT (1988) Oil Crops China 4, 18-22.

[11] Dong JW, Lou SS, Han BW, He ZP and Li PM (1989) Acta Agriculture University Pekinensis 15, 153-156.

[12] Hayat S, Fariduddin Q and Ahmad A (2003) Seed Technology 25(1), 45-49.

[13] Akbari N, Barani M and Ahmadi H (2008) World Applied Sciences Journal 5(2), 199-203.

[14] Chauhan JS, Tomar YK, Singh NI, Ali S and Debarati (2009) Journal of American Science 5(5), 79-84.

[15] Yadav M S and Singh S K (2014) Journal of Pharmacognosy and Phytochemistry 3(2), 216-220.

[16] Singh P and Malik CR (1988) Proceedings of the Indian National Science Academy Part B Biological Sciences 54(6), 413-416.

[17] Yoshida S (1972) Annual Review of Plant Physiology 23, 437-464.

[18] Rao M (1990) M.Sc. thesis, University of Agricultural sciences, Bangalore, Karnataka, India.

[19] Sinha SK, Bhargava SC and Baldev B (1988) Oxford and IBH Publishing, New Delhi, India, 421-455.

[20] Yan W and Wallace DH (1995) Plant Breeding Reviews 13, 141-177.

[21] Islam MR, Prodhan AKMA, Islam MO and Uddin MK (2010) Journal of Agricultural Research 48(1), 73-80.

[22] Jahan N and Khan S (2014) Journal of the Asiatic Society of Bangladesh Science 40(1), 89-96.

[23] Parmar V K, Dudhatra M G and Thesiya N M (2012) Legume Research $35(1), 81-82$.

[24] Quaderi RS, Islam SMA, Hossain AFMGF, Hoque MM and Haque MS (2006) International Journal of Botany 2(1), 42-47.

[25] Sheldrake A R and Saxena N P (1979) New York. John Wiley,465-483

[26] Singh BR (2001) M.Sc. thesis, Punjab Agricultural University., Ludhiana, Punjab, India.

[27] Ganiger TS, Kareekatti SR and Patil BC (2002) Karnataka Journal of Agricultural Sciences 15(4), 701-704.

[28] Bai DIS, Abraham AT and Mercy ST (1987) Legume Research 10, $49-52$.

[29] Sengupta K, Banik NC, Bhui S and Mitra S (2011) Journal of Crop and Weed 7(2), 152-154.

[30] Ramesh R and Ramprasad E (2013) Helix 6, 441 - 447.

[31] Rahman MS, Islam N, Tahar MA and Karim MA (2004) Pakistan Journal of Biological Sciences 7(11), 1851-1857.

[32] Taiz L and Zeiger E (1998) Sinauer Associates, Inc., Publishers, Sunderland, Massachusetts.

[33] Withers WJ and Forde BJ (1979) New Zealand Journal of Agricultural Research 22, 561-569.

[34] Farrington P and Pate JS (1981) Australian Journal of Plant Physiology 8, 293-305.

[35] Scully BT and Wallace DH (1990) Journal of the American Society of Horticultural Science 115, 218-225.

[36] Thomson T, Patel G S, Pandya K S, Dabhi J S and Pawar Y (2015) International Journal of Farm Sciences 5(1), 8-13.

[37] Upadhyay RG (2002) Legume Research 25(3), 211-214.

[38] Reddy A A (2009) Economic and political weekly 52,73-80.

[39] Sharma-Natu P and Ghildiyal MC (2005) Current Science 88, 1918-1928.

[40] Fariduddin Q, Hayat S, Ali B and Ahmad A (2006) Acta Botanica Croatica 65(1), 19-23.

[41] Fariduddin Q, Hasan SA, Ali B, Hayat S and Ahmad A (2008) Turkish Journal of Biology 32, 17-21.

[42] Dhashnamurthi V, Sanchita, Vijay K, Srividhya, Sundaram and Chenniappan V (2013) International Journal of Agricultural Science \& Technology 1(1), 1-8.

[43] Rajesh K, Reddy SN and Reddy APK (2014) Asian Journal of Plant Science and Research 4(3), 35-39.

[44] Reddy P, Ninganur BT, Chetti MB and Hiremath SM (2009) Karnataka 
Journal of Agricultural Sciences 22(2), 289-292.

[45] Sinha SK (1977) Paper No 3, FAO, Rome.

[46] Dangwal D, Maikhuri RK, Rawat LS, Negi V and Singh RK (2006) Assessment of symbiotic nitrogen fixing ability of cultivated legumes in two cropping seasons, Central Himalaya.

[47] Ali S and Bano A (2008) Pakistan Journal of Botany 40(6), 2481-2492.

[48] Medhi AK, Dhar S and Roy A (2014) Indian Journal of Plant Physiology 19(1), 74-78.

[49] Majumdar DK (2011) PH1 learning Private Limited, New Delhi, pp.176-178.

[50] Stevenick RFMV (1957) Journal of Experimental Botany 8, 373-381.

[51] Kaul JN, Singh KB and Sekhon HS (1976) The Journal of Agricultural Science 86, 219.

[52] Ramesh K and Thirumurgan V (2001) The Madras Agricultural Journal 88, 465-468.

[53] Arora N, Bansal A and Kaur J (2005) Journal of Research Punjab Agricultural University 42(1), 58-61.

[54] Garai AK and Datta JK (2002) Crop Research of Hisar 23, 300-307.

[55] Rao KLN, Reddy PJR, Mahalakshmi BK and Rao CLN (2005) Annals of Plant Physiology 19, 14-16.

[56] Singh S (2002) M. Sc. Thesis, Punjab Agricultural University, Ludhiana, India.

[57] Bangal DB, Deshmukh SN and Patil VA (1982) Legume Research 5,54-56.

[58] Thavaprakash $N$, Velayudham K, Djanaguiraman M, Subramanian $P$, Panneerselvam S and Prabakaran C (2006) Legume Research 29, 18-24.

[59] Kandil AA, Sharief AE and Mahmoud ASA (2011) Journal of Applied Sciences Research 7(12), 1883-1889.

[60] Khalil S, El-Saeid HM and Shalaby M (2006) Journal of Applied Science Research 2(9), 587-591.

[61] Islam MO, Rahim MA and Prodhan AKMA (2010) Journal of the Bangladesh Agricultural University 8(1), 29-33.

[62] Ibrahim ME, Bekheta MA, El-Moursi A and Gaafar NA (2007) Australian Journal of Basic and Applied Sciences 1(4), 657-666.

[63] Shyam C, Deol JS and Kaur R (2018) Annals of Agricultural Research 39(1), 48-56.

[64] Lynch J M. and Wood M. (1988) Longman Scientific \& Technical, Harlow, 526563.

[65] Theis JE, Singleton PW and Bohlool BB (1995) Soil Biology and Biochemistry 27, 575-583.

[66] Sinclair TR and deWit CT (1975) Science 189, 565-567.

[67] Munier-Jolain NG and Salon C (2005) Plant Cell and Environment 28, $1388-1395$.

[68] Binnie IE and Clifford PE (1998) Crop Science 39, 1077-1082.

[69] Pate JS and Farrington P (1981) Functional Plant Biology 8(3), 307-318.

[70] Ullah MJ, Fattah QA and Hossain F (2007) Bangladesh Journal of Botany $36(2), 127-132$.

[71] Udensi OU, Edu EA, Ikpeme EV and Ntia MI (2013) Annual Review and Research in Biology 3(4), 762-776. 